\title{
Classical Guidance Materials on Career Students Based on INATBKBK Instrument Analysis
}

\author{
Indah Kurniasari', Muh Farozin ${ }^{2}$ \\ 1,2 Program Studi Bimbingan Konseling Program Pascasarjana, Universitas Negeri Yogyakarta. Indonesia \\ e-mail: indahkurku@gmail.com¹ , farosinmuh89@gmail.com²
}

\begin{abstract}
Career guidance delivered through classical guidance is important to note in order to support the success of students in careers in the future. Nevertheless, there is still limited material that is appropriate and in accordance with the needs of students that can be used as a reference or basis by the Guidance and Counseling teacher in providing classical guidance in career fields to students. This study aims to find the right material and as needed for classical guidance in the career fields of students. Samples in this study amounted to 353 from 14 public high schools. The research method used is descriptive quantitative through the INATBKBK questionnaire method to collect research data. These 10 topics are the basis of material and references that can be used and developed by counseling guidance teachers in the delivery of career guidance through classical guidance to children. With the existence of concrete material for career guidance, career guidance provided through classical guidance is expected to help students to more mature in preparing for the career they will pursue in the future.
\end{abstract}

Keywords: Career Guidance, INATBKBK, Classical Guidance Material

\section{Introduction}

Career is a job or profession that is followed by a person. Someone will work happily, with joy if what is done is in accordance with their abilities and interests. Samsudin (Muspawi, 2017) Career is a number of work positions that a person has held for work life cycle from the lowest position to the top position. Winkel (Nulhakim \& Ibnukhalilulloh, 2018) stated that career guidance is guidance in preparing to face the world of work, in choosing a certain job field or position / profession and equipping oneself to be ready to assume that position, and in adapting to the various demands of the work field that has been entered.Nathan \& Hill (Tumanggor et al., 2018) Careers are a lifelong process, chosen and determined to go through a process that not only takes into account the personal strengths and weaknesses of individuals but focuses on the extrinsic aspects of satisfaction in choosing jobs such as money, status and working conditions. Often times, a person has difficulty when faced with the situation of determining career choices through consideration of one's own suitability to reach a future life. (Tumanggor et al., 2018) Experience in the field shows that there are still many students who are confused about choosing majors or study programs that will be entered especially for senior high school students. Some students make career plans based solely on their wishes and desires without considering their abilities, even where students submit career options to peers or others. Furthermore, (Patton, \& McMahon, 2014) it states life-long career development is a process of gaining satisfaction by making adjustments to personal and environmental choices ). Careers are closely related and are an important part of satisfying success in living the present and future life that someone will experience (Cut Wahyuni \& Nurdin, 2017).

Explaining a person's career, guidance is needed in making the selection. At the formal school stage the guidance carried out at the career selection stage is facilitated by the guidance and counseling teacher. This is expected to help students in choosing career fields. (Hadi, 2017) Guidance is assistance to individuals in dealing with problems that can arise in his life. Help of some kind it is very appropriate if given at school, so that each student is more develop in the maximum possible direction. Suherman (Agungbudiprabowo et al., 2018) career guidance is a process of helping a person to understand and accept a picture of himself and a

\footnotetext{
${ }^{*}$ Corresponding author.

Received 07 October 2020; Accepted 11 November 2020; Available online 25 March 2021 (C) 2020 JPI. All Rights Reserved
} 
picture of the world of work outside of himself, bringing that image of himself together with the world of work so that in the end he can choose a field of work, enter it and build a career in that field. In line with the above opinion career guidance is a type of guidance that tries to help individuals solve career problems, career guidance is focused on helping students understand their potential in order to develop their career life and be able to understand their role as workers and how the counselee can integrate his role as a worker with other life roles, for example his role as a family member and other things.

Formal school stages to help individuals determine career choices through career guidance, one of which is carried out during junior high school. Freud (Saputro, 2018) adolescence there is a developmental process including changes related to psychosexual development, as well as changes in relationships with parents and their ideals, where the formation of ideals is a process of shaping future orientation. Adolescence is a period of transition or transition from childhood to adulthood. Junior high school students need services and direction from career guidance and counseling in order to be able to develop optimally and be able to organize their future well in career choices. During early adolescence, students become increasingly aware of their own interests and abilities, as well as their values, and they argue that this self-awareness is the key to career growth in early adolescence.(Gantina, 2015) explains that the Super theory states that the career development of students in junior high school is at the sub-stage of capacity and begins to enter the career exploration stage. At this stage, students have high curiosity and try to explore and consider various career information (self-potential, high school, and information on the world of work).

(Keumala et al., 2018) The most dominant stage of career growth in primary schoolaged children is the development of fantasy, interest, and career ability. Super career growth is designed for future planning, enhancing personal control over individual lives, developing awareness of the importance of school achievement and work, and gaining a competent work attitude. In accordance with the Super scheme at the stage of growth, the child will go through various learning activities experiences when developing greater selfawarenes. (Hermawan \& Farozin, 2018) Career exploration is important because it selects goals and flows to achieve future goals so that learners can make career decisions appropriately according to their interests and talents. Adiputra (2015) explains that in the phase of students entering junior high school or adolescence, good career guidance is needed for students, the goal is that students can plan careers by understanding their potential and their interest in a job. Furthermore, Adiputra explained that career information at junior high school is for the development of interest and value towards guidance at this age, namely how students can develop their interests, how students can develop their interests and values.

Continuing the explanation about careers, the delivery of counseling guidance that is applied in formal schools is one of which is done at the junior high school stage. The delivery of career guidance and counseling information will be more effective if it is done classically because with a lot of material it can be conveyed to students / large audiences quickly and evenly. One of the good discussions to pass on is about the career he will choose. Guidance and Counseling services in schools that are most often carried out are classical guidance, which is a strategy for guidance services provided to students through a face-to-face process with students in the classroom on a scheduled basis and contained in programs compiled by the Guidance and Counseling Teacher. (Fandini \& Purwoko, 2018) Classical information service strategy as one of the strategies in the Counseling Guidance service has the aim of launching service activities that can develop student potential or achieve developmental tasks so that they can achieve educational tasks. (Mukhtar et al., 2016) suggest that classical guidance is a service provided to students in a number of class units between 30-40 people through classical activities that are presented systematically, are preventive in nature and provide self-understanding and understanding about other people who are oriented towards learning, personal, social, and career with the aim of providing accurate information and can help individuals to plan decision-making in their lives and develop their potential optimally. Furthermore, it is conveyed that career guidance can be provided properly using classical guidance. (Mulawarman et al., 2020) classical guidance must be made as attractive as 
possible, it is not only the material that needs attention, but the method / method of delivery must also be efficient.

(Saifuddin et al., 2017) Since adolescence someone has faced with choosing and preparing oneself to carry out a job or career because of work or career a person determines various things in lifeTalking about careers and classical guidance in the selection made by individuals. The researcher determines the main reference material for the standard reference of counseling through classical guidance. In line with this statement, Suherman (Andriati et al., 2020) suggests that individuals (adolescents) will experience problems in his career if the individual is in one of the following conditions; 1) broad knowledge about themselves but narrow about the world of work, 2) narrow knowledge about themselves but broad knowledge about the world of work, 3) narrow knowledge about themselves and the world of work, and 4) broad knowledge of themselves and the world of work. This is in line with the suggestion (Lestari, 2017) Career problems that occur at adolescents are usually concerned with choosing the type of education, which leads to choosing the type of work in the future. This issue is important to pay attention to in connection with the many confusion that adolescents experience in determining their career direction. Not only that, career indecisiveness in adolescents will result in the maturity level of personality development. Trisnowati (2016) argues that the lack of information related to education, position or occupation that matches the ability of students is also one of the obstacles for students from not making proper career decisions. The results of research conducted by Lestari (Agungbudiprabowo et al., 2018) in adolescents who have graduated from high school indicates that $33 \%$ of students are on vocational identity status achievement (identity achievement), $18 \%$ of students have moratorium identity status (postponement identity). As many as $19 \%$ of students are on foreclosure identity status (identity revocation) and the remaining $34 \%$ of students are on diffusion identity status (spread identity) especially in terms of career planning. Guidance and counseling roles needed in schools to answer these problems, one of which is by providing information through classical career guidance with good material.

(Nuranisa \& Wiyono, 2018) classical guidance services can be done, but they are not effective due to a lack of motivation from the students' side to participate in these activities Ideally, in determining the classical service material to be provided, it is compiled by considering the students' assessment. (Pristanti \& Farozin, 2018) Classroom guidance was part of basic services. Classroom guidance could be used as a strategy in providing social class guidance counseling and counseling services to preprogrammed learners who are composed of guidance and counseling teachers. Guidance and counseling programs were prepared based on the analysis of the need assessment. The standard types of standard need assessment tools currently available are "Alat Ungkap Masalah" (AUM), Checklist of Problems (DCM), Developmental Task Inventories (ITP), and other developed instruments. Each instrument had their own weaknesses and advantages. DCM only reveals problems that occur to students, AUM only reveals problems regarding learning, as well as ITP which only shows the percentage of development between one student and another so it is a little confusing in formulating student needs regarding the topic of classical guidance. Therefore, researchers want to use standardized instruments to reveal students' needs regarding classical guidance material topics in the field of career guidance and counseling services, namely the instrument needs assessment of classical guidance topics in the field of career guidance and counseling services (INATBKBK) which has been developed by previous researchers who will more effective because it immediately reveals what students need.

This study aims to find topics and sub-topics of classical guidance material in the career field that suit the needs of students so that they can contribute scientifically in the development of career guidance and counseling. The urgency of this research is considering that the preparation of material in the field is still varied and in the field, material topics are needed as a reference as a basis for teachers in providing classical guidance services in the career field, with this research it is hoped that it can produce topics and sub-topics of classical guidance in the career field in junior high schools. who will be used as junior high school guidance and counseling teachers in providing classical services in the career field according to student needs. 


\section{Method}

The research method used is descriptive quantitative through the INATBKBK questionnaire method to collect research data. The Need Assessment instrument is one way or method to find out the difference between the expected conditions and the existing conditions. This instrument has passed the validity and reliability analysis of guidance and counseling experts and practitioners with an average face validity assessment of $77 \%$ or 0.77 . The content validity using the Aiken formula obtained 0.83 , and the reliability using the Alfa Cronbach formula was obtained 0.93 so it revealed that this questionnaire was good for use in research. The benefit of this instrument is that students get topics and sub-topics according to their needs. In the INATBKBK questionnaire, students were asked to determine the level of need for 34 statement items relating to the topic of classical career guidance.

The total population of grade VII students in Yogyakarta City State Junior High School, amounting to 3031 students, sample in this study amounted to 353 students of SMPN from 14 schools with A accreditation in Yogyakarta. The sample size of 353 respondents was determined from the targeted population (3031) using purposive technique with Slovin formula. Then the technique of proportional stratified sampling hired to select respondents from each of the 14 secondary schools in Yogyakarta. The research was carried out on February 4, 2019 - March 1, 2019 in class VII at Yogyakarta City State Junior High School for the 2018/2019 academic year.

The analysis technique in this research is according to the instructions contained in the INATBKBK instrument manual with the following stages: (1) Calculating the total number of respondents' choices using Microsoft Excel, (2) Writing down the student's answers according to typing one of the checked answer options, namely SMBT, SMKT, SMT, MBT, MKT, MT, KMBT, KMKT, KMT, OR,TM, (3) Typing the formula listed in the manual, (4) Pulling the formula (drag) from top to bottom, (5) Typing the formula = SUM (respondent's score 1: last respondent's score) on each item item. That is, the scores are added from the first respondent to the last respondent on each item, (6) Determining the priority scale of the needs for the topics and sub-topics of classical guidance in the field of career guidance and counseling services at the highest number, (7) The score that reaches the highest value is indicated by in blod or in bold, (8) the 10 highest scores on the priority criteria were selected to be the topic of classical guidance services in career fields.

\section{Result and Discussion Result}

Based on the results of research that has been done by filling out the Instrument Need Assessment Questionnaire for Class VII Classical Classical Guidance (INATBKBK) at Yogyakarta City Junior High School, from 34 topics in the INATBKBK questionnaire, 10 topics of good field classical guidance service material are needed by students for 1 semester. Material that is good and in accordance with the needs of students is presented in table 1 below.

Table 1. Topic Classical Career Guidance for Class VII SMPN Students

\begin{tabular}{|c|c|c|c|c|c|}
\hline $\begin{array}{l}\text { No. } \\
\text { Item }\end{array}$ & Topic & Sub Topic & Service Topic & $\begin{array}{l}\text { Total } \\
\text { Skor }\end{array}$ & informaton \\
\hline $4 . b$ & $\begin{array}{l}\text { Understanding self- } \\
\text { efficacy }\end{array}$ & $\begin{array}{l}\text { Understand self- } \\
\text { efficacy in career } \\
\text { selection }\end{array}$ & $\begin{array}{l}\text { Recognize abilities, } \\
\text { interests and } \\
\text { personality and } \\
\text { direction } \\
\text { career trends / } \\
\text { ideals }\end{array}$ & 1586 & Priority \\
\hline 29.a & $\begin{array}{l}\text { Talent in } \\
\text { improving } \\
\text { academic } \\
\text { skills }\end{array}$ & $\begin{array}{l}\text { Knowing the talents } \\
\text { you have }\end{array}$ & $\begin{array}{l}\text { Talent interest in } \\
\text { me }\end{array}$ & 1562 & Priority \\
\hline
\end{tabular}




\begin{tabular}{|c|c|c|c|c|c|}
\hline $\begin{array}{l}\text { No. } \\
\text { Item }\end{array}$ & Topic & Sub Topic & Service Topic & $\begin{array}{l}\text { Total } \\
\text { Skor }\end{array}$ & informaton \\
\hline $27 . e$ & $\begin{array}{l}\text { Have an interest in } \\
\text { improving non- } \\
\text { academic }\end{array}$ & $\begin{array}{l}\text { Understand the } \\
\text { benefits of having } \\
\text { skills }\end{array}$ & My work skills & 1547 & Priority \\
\hline 30.d & $\begin{array}{l}\text { The journey of } \\
\text { human life in } \\
\text { planning a career }\end{array}$ & $\begin{array}{l}\text { Understand career } \\
\text { planning goals }\end{array}$ & My career plan & 1542 & Priority \\
\hline $5 . d$ & $\begin{array}{l}\text { Understand job and } \\
\text { career information }\end{array}$ & $\begin{array}{l}\text { Understand the } \\
\text { difference between } \\
\text { work and career }\end{array}$ & $\begin{array}{l}\text { Know the difference } \\
\text { between jobs and } \\
\text { careers }\end{array}$ & 1538 & Priority \\
\hline $5 . a$ & $\begin{array}{l}\text { Set the time for } \\
\text { the desired } \\
\text { education and } \\
\text { career }\end{array}$ & $\begin{array}{l}\text { Applying the way of } \\
\text { building free time }\end{array}$ & $\begin{array}{l}\text { Get to know } \\
\text { extracurricular } \\
\text { activities at school }\end{array}$ & 1535 & Priority \\
\hline 34.a & $\begin{array}{l}\text { Reaching for } \\
\text { career goals in } \\
\text { the future }\end{array}$ & $\begin{array}{l}\text { Cultivate career } \\
\text { goals }\end{array}$ & $\begin{array}{l}\text { My future career } \\
\text { goals }\end{array}$ & 1535 & Priority \\
\hline 28.c & $\begin{array}{l}\text { Adjust academic } \\
\text { skills in choosing } \\
\text { a career }\end{array}$ & $\begin{array}{l}\text { Apply an effort to } \\
\text { match skills in } \\
\text { choosing a } \\
\text { career }\end{array}$ & $\begin{array}{l}\text { Understand } \\
\text { my academic } \\
\text { skills }\end{array}$ & 1533 & Priority \\
\hline 19.b & $\begin{array}{l}\text { Overcome problems } \\
\text { in career selection }\end{array}$ & $\begin{array}{l}\text { Understand the } \\
\text { conditions that create } \\
\text { problems in career } \\
\text { choice }\end{array}$ & $\begin{array}{l}\text { Identify the barriers } \\
\text { to career choice }\end{array}$ & 1530 & Priority \\
\hline $5 . d$ & $\begin{array}{l}\text { Understand job } \\
\text { information } \\
\text { and career }\end{array}$ & $\begin{array}{l}\text { Understand the types } \\
\text { of professions in the } \\
\text { world of work }\end{array}$ & $\begin{array}{l}\text { Get to know the } \\
\text { types of professions } \\
\text { in the era millennial }\end{array}$ & 1525 & Priority \\
\hline
\end{tabular}

Based on the results of the questionnaire analysis that has been filled in by the research sample, it was found that ten topics were good and in accordance with the needs of students which could be used as a basis for being able to develop material in classical guidance in career fields for SMPN students throughout Yogyakarta City. The first material that can be used as a basis for making material on the topic of understanding the abilities of each student, on this topic requires students to recognize the strengths and abilities that can be developed and come from themselves. Sub-topics that must be understood by students are about the abilities possessed by themselves being able to be adjusted to the career choices in the future. Service topics that can be used by the teacher include the introduction of abilities, interests and personalities that have a tendency to be career choices or student aspirations.

The next topic discussed in making material about talents can improve academic abilities that will support student careers, sub topics discuss students starting to explore and must be able to know consciously about their talents. The next topic concerns the interests and talents of students' skills outside of non-academic skills which will be of good use in determining the career and goals to be chosen. The ambiguity of the topic about the importance of career planning from an early age to find out the goals and career desires that will be undertaken in the future. The next topic is about information about careers, knowing the differences between jobs and careers to be undertaken. Topics that are no less important are about time management regarding education with the career that students want, how to do things that can support careers in their spare time, by doing extracurricular activities outside of school which might later become a student career choice.

Other material topics are about ways on how students can achieve the career goals they want in the future, how to grow and improve their career aspirations in the future. Students are able to realize academic skills so that they are able to adjust to the choice of career that will be carried out in the future, students are able to apply efforts to adjust skills in choosing a career. The follow-up topic is how students are able to overcome the problems they will face 
in their future career choices; students are able to consciously understand the conditions of problems that will arise in career choices. Finally, the topic that must be studied is to understand carefully and detail job and career information, students are able to understand the types of professions at work, students are able to identify the types of work in the millennial era. These ten topics are material that is appropriate and best given to the age of SMPN students in career guidance.

\section{Discussion}

Classical guidance material in the field of career for class VII students of SMP Negeri Yogyakarta was developed by selecting the top 10 topics from the analysis of instrument needs assessment, the topic of classical guidance in the field of career guidance and counseling services, then the 10 highest topics were developed into service topics. The total of 10 materials is based on the equivalence of classical guidance that can be carried out for one semester, namely considering the effective school days where the school has 20 effective weeks in one semester to provide classical services in personal, social, study and career fields. So that 2 semesters of classical guidance in the career field require 10 service materials delivered during one hour of subjects a week (40 minutes for junior high school students).

About character education. Based on the research results, there are 10 materials that can be used as a basis for guidance using modeling techniques in career guidance for SMPN students. Counseling guidance using a casical model is considered to be very effective in conveying career knowledge to students. With this material, it is hoped that it can maximize the career guidance of SMPN students so that students do not hesitate to pursue a career because they have been given career guidance and students are able to find out and develop their abilities so that they can be pursued into jobs and careers that students will undertake in the future.

The results of this study are related to a review of previous research literature which suggests the importance of career guidance and guidance through classical methods which are good for delivering careers to students and the importance of development as a basis for delivering career guidance through classical guidance methods. In line with this statement, (Hasana, 2017) Based on the results of data collection related to needs development of educational teaching materials Project Based Learning based character shows that most of the SMP in the city of Semarang stated there was not yet specific teaching materials related to character building. Existing teaching materials so far it is still related to the guide implementation of character education issued by the Ministry of Education National year 2011. Secondary School First in the city of Semarang in general does not have specific teaching materials. Teachers in providing material about character education usually take from character education manuals, the internet, and literature books on character education in providing material related to character education in addition to habituation activities that have been routinely carried out. A special guide or teaching material is needed that can be used by teachers in integrating character education in schools. The results of this study are in line with this research, where there are no specific teaching materials related to classical career guidance. Muya (Pristanti \& Farozin, 2018) revealed on the Evaluation of the Implementation of Basic Social-Social Services at SMP Negeri 1 Yogyakarta stated that at the planning stage of the basic social-private service program, the counselor undertaken the needs assessment of basic personal- social by using ITP (Inventory development task) in the form of a series of statements about a condition that may occur to the respondent / student However, Teacher guidance and counseling experience barriers in analyzing inventory development tasks. Teacher guidance and counseling also have difficulty in developing the topic of classroom guidance services in the field of social counseling and guidance services. Therefore, researchers are interested in conducting related research classical guidance materials on career students in smpn based on inatbkbk instrument analysis which can be used by guidance and counseling teachers when doing classical guidance in career fields

(Nurlela \& Surtiyoni, 2020) The obstacles of students in planning their careers are dominated by internal factors, which are related to the understanding of their abilities. While external factors that affect students so that the difficulty in choosing a career caused by conflict 
between lifestyle demands with the ability to adapt to changes in lifestyle. This study recommends In the context of the development of knowledge, especially in the field of counseling guidance, it is expected that there is research related to obstacles and solutions to career planning for students. This research can also be used as a reference material to produce updated research results that are relevant to career obstacles. With the latest research will provide a reference to the differences from this study with further research. For research counseling teachers, this research can be used as material for implementing counseling and guidance service programs, especially in the field of career service. (Akhsania et al., 2020) These findings recommend the students to improve their career decision making using career guidance and counseling strategies in form of various alternative services, such as career counselling services, group guidance, classroom service, and even support from other parties. (Gendon, 2008) describes the need for material development to become a basis and reference in making developments for curriculum preparation and evaluation of BK programs, including in providing services and career guidance to students. Service regarding career information is very good provided to students.

According to a consistent body of research, this study is designed to explore the contribution of career decision self-efficacy, locus of control, academic self-esteem, personality traits and parenting support for prediction of career doubt among adolescents. Career control location, academic self-esteem and neuroticism were significant predictors of career doubt. The main results are discussed in the context of their relevance for counseling adolescents in career choice and development. (Falentini et al., 2013) revealed the need for a career introduction so that students are able to make their career choices and try to find out the future prospects for work to be chosen through the internet, the dominant factor considered by students in determining career choices is the freedom to choose education. What is desired after graduation, the dominant obstacle students encounter in determining career choices is that friends provide different input about career choices. All significant career stages are predicted by different personality traits.

(Oktaviani.J, 2018) Career planning is important because with career planning it will reduce the tension and confusion of individuals in finding career information in making career decisions. A mature career planning at school can help someone to get to know and understand their talents and interests better. The ability to plan careers needs to be possessed by every individual, including students in schools. Career planning that is owned by students is useful for choosing the type of further study, and choosing a job plan. Efforts to improve student career planning in school can be reached through guidance and counseling services. (Arjanggi, 2017) Based on the results of research data analysis, it is known that the difficulty level of adolescent career decision making is still high. The results of statistical tests on differences in the difficulty of making career decisions based on gender show that young girls are more difficult in making career decisions. Therefore, they need to get full career information, guidance and mentoring services in order to obtain an adequate understanding of the various conditions and characteristics of themselves, both about their talents, interests, aspirations, various strengths and weaknesses in themselves and not wrong in determining their career. which he chooses.(Nuraini et al., 2019) result of this research showed there was an improvement of the career aspirations of the student after receiving a career information service. (Ramdhani et al., 2018) The results of the study show that in general the career adaptability of students in Business Management Education is in the medium category with the character of students having concern, control, curiosity and confident, but there are still behaviors that do not reflect the four dimensions of career adaptability. Recommendations are shown to further researchers so that they can provide follow-up to improve early adult career adaptability.

Izzaty (Pritangguh, 2017) Adolescence is the first step to starting career planning. Adolescence is an important period, a transition period, a period of change, the search for identity, problematic age, fear age, unrealistic period, and adulthood threshold. Career delivery requires guidance and career services so that students are more capable of can determine and plan a career that will be undertaken carefully. (Adiputra, 2015) revealed that modeling techniques for career planning are important things that teachers of guidance and counseling 
must provide to students. Furthermore, Adiputra explained that by using the modeling technique for student career planning, it was able to provide a high level of effectiveness to the career choices of students who would be chosen and implemented in the future with career planning like this being able to direct and win student careers in the future, students were able to exploit their abilities and develop their abilities according to their career plans. The level of student karor knowledge increases after being given career services, so that students are better able to determine and prepare well for a career that will be undertaken in the future according to their talents, interests and abilities. The material and foundation in providing career material must be adjusted to the phases and stages of the child's age development (Kamil \& Daniati, 2016).

Juwitaningrum, (2013) revealed that the phenomenon of Vocational School student confusion regarding the career to be taken. Many of the education that is being taken is not in line with the career you really want. So that career counseling is needed with introductory material and career planning, the result is that the Career Guidance program is proven to be effective in increasing student career maturity so that it is feasible to be applied in Guidance and Counseling services.(Rahmi \& Puspasari, 2017) The career maturity of adolescence is at an exploratory stage (15-24 years) At this stage the individual explores various types of work, assesses himself, and has think of various career alternatives according to their abilities, adolescents who are mature in their careers will be able to complete the stage of their career development, adolescents with high career maturity tend to get information that helps and directs them in choosing a career in their future. In line (Muttaqin et al., 2017) The introduction and understanding of further education or careers is a process of stages of vocational development students towards the right career selection. Introduction and understanding of careers should be done as early as possible to avoid making mistakes in career choice. The decision to choose a particular job, position, and career is a series of consequences of decisions made by individuals during the past stages of their life. ( Mihaela \& Cristina, 2015) explained that young people need counseling and guidance to be able to discover their abilities, trends and outline for their future. Career guidance and counseling should be made permanent from primary and secondary education. In delivering careers, guidelines and materials are needed to be developed and then conveyed to students regarding career planning. Most of the career issues raised in life design career counseling are career choices in the individual's life. In addition, various studies have shown that life design career counseling by determining age-appropriate material when delivering appropriate career experiences is applied in various countries, such as Portugal, Italy, the United States, and South Africa. The recommendation for content analysis is to develop life design career counseling research in Indonesia, especially in schools (Cahyawulan, 2017).

(Pujiastuti \& Barat, 2018) Based on the observations and the results of the assessment, it was found that with career information services, student activities were increasing. In providing guidance regarding career information services, there should be full assistance in order to obtain an adequate understanding of the various conditions and characteristics of him, both about his talents, interests, aspirations, various strengths and weaknesses in him and not wrong in determining the career he chooses. (Anwar, 2017) The collection of information about careers covers the type of career, culture, mission, areas of specialization in the career field, and current issues. This will help students understand various kinds of career information. The process of introducing and gathering career information is the main step in exploring a student's career. After students are able to know and have various information about their careers, students will plan actions and make decisions in their careers. The integration between self-understanding and self-understanding as well as gathering information about careers will make students' careers more mature, planned, systematic and in accordance with their interests and talents. (Vitale, 2016) prepares all students for college and careers, and the grant expresses greater autonomy than in the past regarding how they ensure student progress towards their readiness for the world of work later. Students are prepared to be able to find out the career goals and jobs they want to do in the future. (Eriksson et al., 2018) revealed that classical career guidance activities that aim to contribute to knowledge about the labor market, programs and courses and requirements for different educational programs 
might be considered more beneficial by young adults if they are organized in a combination of various level, academic. Both as group activities (exhibitions, general information / discussion) and individual activities (personal information / discussions). The relevance of this research is that it is equally related to the provision of services in the classroom.(Farozin, 2012) classical guidance is effectively used to increase the learning motivation of junior high school students in Kulon Progo with an increase contribution of $44.9 \%$. The relevance of this research is to show that classical guidance is a service that is preventive, curative, preservative, and developmental and is an efficient way of providing information to students in a number of class units, and shows that classical guidance is very effective and efficient in providing information to a number of participants students in the form of class units. Classical guidance materials on career students in smpn based on inatbkbk instrument analysis it is hoped that it can become a reference or guide when guidance and counseling teachers will provide classical guidance services in career fields to students.

\section{Conclusions and Suggestions}

Based on the results of research that has been done regarding INATBKBK as a basis in making material for classical guidance career guidance for junior high school students. It was found that from the 34 INTBKBK questionnaire questions there were 10 suitable questions to be used in career guidance for this semester, the ten good service materials were used, namely, recognizing abilities, interests and personality as well as direction of career trends / ideals, talents, interests in me, skills my job, my career plan, recognizing the difference between work and career, getting to know extracurricular activities in school, my future career aspirations, understanding my academic skills, recognizing obstacles in career choices, recognizing obstacles in career choices. With the career guidance provided through classical guidance it is hoped that it will help students to be more mature in preparing for the career they will undertake in the future, providing career guidance is very useful so that students are able to determine one goal for work and become a focus to be able to develop their abilities to support them career success.

\section{References}

Adiputra, S. (2015). Penggunaan Teknik Modeling Terhadap Perencanaan Karir Siswa. Fokus Konseling, 1(1), 45-56. https://doi.org/10.26638/jfk.70.2099

Agungbudiprabowo, A., Nurhudaya, N., \& Budiamin, A. (2018). Efektivitas Program Bimbingan Karir Berbasis Teori Super untuk Mengembangkan Identitas Vokasional Remaja. Jurnal Psikologi Pendidikan Dan Konseling: Jurnal Kajian Psikologi Pendidikan Dan Bimbingan Konseling, 4(1), 14. https://doi.org/10.26858/jpkk.v4i1.5725

Akhsania, K. N., Basuki, T., Sugiharto, D., \& Japar, M. (2020). Students ' Career Understanding and Career Decision Making Self-Efficacy in Junior High School. Islamic Guidance and Counseling Journal, 4(1), 12-20. https://doi.org/10.25217/igcj.v4i1.950

Andreea Mihaela, N., \& Goga Cristina, I. (2015). a Research on the Educational Counseling and Career Guidance in Romania. European Scientific Journal, 2(February), 18577881.

http://citeseerx.ist.psu.edu/viewdoc/download?doi=10.1.1.679.9271\&rep=rep1\&type= pdf\#page =36

Andriati, N., Maulana, R., Hartinah, G., \& Sukmawati, E. (2020). Pengembangan Model Layanan Informasi Berbantu Media Visual Untuk Meningkatkan Pemantapan Karier Pada Siswa Sma Negeri Di Kabupaten Kubu Raya. Sosial Horizon: Jurnal Pendidikan Sosial, 7(1), 104-120.

Anwar, M. K. (2017). Model Eksplorasi Karir Sebagai Upaya Persiapan Karir Siswa Dalam Menghadapi ASEAN Global. Gujigang, 3(1), 53-57. https://www.academia.edu/download/58112090/MODEL_EKSPLORASI_KARIR_SEB AGAI_UPAYA_PERSIAPAN_KARIR_SISWA_DALAM.pdf

Arjanggi, R. (2017). Identifikasi Permasalahan Pengambilan Keputusan Karir Remaja. 
Psikologika: Jurnal Pemikiran Dan Penelitian Psikologi, 22(2), 28-35. https://doi.org/10.20885/psikologika.vol22.iss2.art3

Cahyawulan, W. (2017). Konseling karier life design: analisis konten jurnal the career development quarterly tahun 2016. Proceeding Seminar Dan Lokakarya Nasional Revitalisasi Laboratorium Dan Jurnal IImiah Dalam Implementasi Kurikulum Bimbingan Dan Konseling Berbasis KKNI, 282-290.

Eriksson, H., Högdin, S., \& Isaksson, A. (2018). Education and career choices: How the school can support young people to develop knowledge and decision-making skills. Universal Journal of Educational Research, 6(9), 1900-1908. https://doi.org/10.13189/ujer.2018.060907

Falentini, F. Y., Taufik, T., \& Mudjiran, M. (2013). Usaha Yang Dilakukan Siswa Dalam Menentukan Arah Pilihan Karir Dan Hambatan-Hambatan Yang Ditemui. Konselor, 2(1), 310-316. https://doi.org/10.24036/02013211266-0-00

Fandini, shella hario, \& Purwoko, B. (2018). Pengembangan Adobe Flash Sebagai Media Layanan Informasi Peminatan Studi Lanjut Sma Dan Sederajat Untuk Siswa Kelas Ix $\begin{array}{llllll}\text { Smpn } & 5 & \text { Sidoarjo. Jurnal } & \text { B } & \text { Unesa, }\end{array}$ https://jurnalmahasiswa.unesa.ac.id/index.php/jurnal- bk-unesa/article/view/22735

Farozin, M. (2012). Pengembangan Model Bimbingan Klasikal Untuk Meningkatan Motivasi Belajar Siswa Smp. Jurnal Cakrawala Pendidikan, 1, 143-156. https://doi.org/10.21831/cp.v0i1.1472

Hadi, S. (2017). Peran Dan Tanggung Jawab Staf Sekolah Dalam Bimbingan Dan Konseling Bagi Siswa. Jurnal Tatsqif, 15(2), 211-222. https://doi.org/10.20414/jtq.v15i2.9

Hermawan, R., \& Farozin, M. (2018). The role of career exploration in career decision participants. COUNS-EDU: The International Journal of Counseling and Education, 3(4), 126. https://doi.org/10.23916/0020180315640

Juwitaningrum, I. (2013). Program Bimbingan Karir untuk Meningkatkan Kematangan Karir Siswa SMK. PSIKOPEDAGOGIA Jurnal Bimbingan Dan Konseling, 2(2), 132. https://doi.org/10.12928/psikopedagogia.v2i2.2580

Kamil, B., \& Daniati, D. (2016). Layanan Informasi Karir dalam Meningkatkan Kematangan Karir pada Peserta Didik Kelas X Di Sekolah Madrasah Aliyah Qudsiyah Kotabumi Lampung Utara Tahun Pelajaran 2016/2017. KONSELI: Jurnal Bimbingan Dan Konseling (E-Journal), 3(2), 175-190. http://www.ejournal.radenintan.ac.id/index.php/konseli/article/view/565

Keumala, E., Nurihsan, J., \& Budiamin, A. (2018). The Development of Career Learning Program with Modeling Technique to Improve Student Career Awareness. Islamic Guidance and Counseling Journal, 1(2), 53. https://doi.org/10.25217/igcj.v1i2.270

Lestari, I. (2017). Meningkatkan Kematangan Remaja Melalui Bimbingan Karir Berbasis Life Skills. Jurnal Konseling Gusjigang, 3(1), 21. https://core.ac.uk/download/pdf/304202219.pdf

Mukhtar, M., Yusuf, S., \& Budiamin, A. (2016). Program Layanan Bimbingan Klasikal untuk Meningkatkan Self-Control Siswa. PSIKOPEDAGOGIA Jurnal Bimbingan Dan Konseling, 5(1), 1. https://doi.org/10.12928/psikopedagogia.v5i1.4473

Mulawarman, M., Susilawati, S., Syifa, L., \& Rifani, E. (2020). Classroom Guidance Strategy with Flipped Method in Guidance and Counseling Services at Indonesia Schools in the Digital Era. Islamic Guidance and Counseling Journal, 3(2), 61-74. https://doi.org/10.25217/igcj.v3i2.646

Muspawi, M. (2017). Menata Pengembangan Karier Sumber Daya Manusia Organisasi. Jurnal IImiah Universitas Batanghari Jambi V, 17(1), 114-122. http://dx.doi.org/10.33087/jiubj.v17i1.108

Muttaqin, R., Wagimin, \& Tadjri, I. (2017). Keefektifan Layanan Informasi Karier Berbantuan Video Interaktif dan Live Modeling untuk Meningkatkan Pemahaman Karier Siswa 
$\begin{array}{llll}\text { SMP. Jurnal Kimbingan } \quad \text { Konseling, } & \text { 6(2), }\end{array}$ http://journal.unnes.ac.id/sju/index.php/jubk\%0AKeefektifan

Nulhakim, L., \& Ibnukhalilulloh, M. (2018). Konsep Bimbingan Karir Kolaboratif Melalui Penguatan Efikasi Diri. Al-Tazkiah, 7(2), 124-141. https://doi.org/10.20414/altazkiah.v7i2.657

Nuraini, P., Tawil, T., \& Subiyanto, S. (2019). The Impact of Islamic-Based Career Information Service to Improve Students Career Aspirations. Islamic Guidance and Counseling Journal, 2(1), 26. https://doi.org/10.25217/igcj.v2i1.242

Nuranisa, N., \& Wiyono, B. (2018). Studi Implementasi Strrategi Bimbingan Klasikal Di Smp Negeri 13 Surabaya. Jurnal BK UNESA, 8(2), 380-387. https://jurnalmahasiswa.unesa.ac.id/index.php/jurnal-bk-

unesa/article/viewFile/24776/22689\%0Ahttps://jurnalmahasiswa.unesa.ac.id/index.ph p/jurnal-bk-unesa/article/view/24776

Nurlela, N., \& Surtiyoni, E. (2020). Barriers to the maturity of student's career planning as millennial generation. Jurnal Psikologi Pendidikan Dan Konseling: Jurnal Kajian Psikologi Pendidikan Dan Bimbingan Konseling, 6(1), 35-41. https://doi.org/10.26858/jppk.v6i1.13442

Oktaviani.J. (2018). Meningkatkan Pemahaman Perencanaan Karir Melalui Layanan Bimbingan Karir di Sekolah Dengan Menggunakan Media Gambar Pada Siswa Kelas Ix-1 Smp Negeri 1 Gebang Tahun 2017-2018. Jurnal Tabularasa PPS UNIMED, 51(1), 51. http://jurnal.unimed.ac.id/2012/index.php/tabularasa

Patton, W., \& McMahon, M. (2014). Career development and systems theory. Sense Publisher.

Pristanti, N. A., \& Farozin, M. (2018). Developing Needs Assessment Instrument On The Topic Of Classroom Guidance In Social Guidance And Counseling. Jurnal Psikologi Pendidikan Dan Konseling: Jurnal Kajian Psikologi Pendidikan Dan Bimbingan Konseling, 4(1), 47. https://doi.org/10.26858/jpkk.v4i1.4775

Pritangguh, M. (2017). Peningkatan Kemampuan Perencanaan Karier Melalui Bimbingan Kelompok Teknik Diskusi Pada Siswa Smpn 3 Kebumen Career Planning Ability Improvement Through Discussion Techniques Group Counseling. E-Journal Bimbingan Dan Konseling, 2(6), 178-187.

Pujiastuti, F., \& Barat, J. (2018). Penerapan Layanan Informasi Karir untuk Meningkatkan Pemahaman Siswa dalam Pengambilan Keputusan Karir. Jurnal Penelitian Pendidikan, 18(2), 160-170.

Rahmi, F., \& Puspasari, D. (2017). Kematangan karir ditinjau dari jenis kelamin dan jenis sekolah di kota Padang. Jurnal RAP UNP, 8(1), 24-35. http://ejournal.unp.ac.id/index.php/psikologi/article/view/7949

Ramdhani, R. N., Budiamin, A., \& Budiman, N. (2018). Adaptabilitas Karir Dewasa Awal. Jurnal Penelitian Pendidikan, 18(3), 361-370.

Saifuddin, A., Ruhaena, L., \& Pratisti, W. D. (2017). Meningkatkan Kematangan Karier Peserta Didik SMA dengan Pelatihan Reach Your Dreams dan Konseling Karier. Jurnal Psikologi, 44(1), 39. https://doi.org/10.22146/jpsi.17378

Saputro, K. Z. (2018). Memahami Ciri dan Tugas Perkembangan Masa Remaja. Aplikasia: Jurnal Aplikasi IImu-IImu Agama, 17(1), 25. https://doi.org/10.14421/aplikasia.v17i1.1362

Tumanggor, H. R., Sunawan, S., \& Purwanto, E. (2018). Improving Career Planning using Website-Based Career Information Service. Islamic Guidance and Counseling Journal, 1(2), 62. https://doi.org/10.25217/igcj.v1i2.239

Vitale, D. (2016). Education and Career Navigation: Critical for Student Progress and Success*. 